\title{
PENGEMBANGAN MODEL KEPUASAN KERJA UNTUK MENGHADAPI TURNOVER INTENTION KARYAWAN PADA PT KITADIN SITE EMBALUT (KALIMANTAN TIMUR)
}

\author{
Murfat Effendi \\ University of 17 Agustus 1945 Samarinda \\ Jl. Ir. H. Juanda No. 80, 75124, Indonesia \\ fendi180676@gmail.com
}

\begin{abstract}
This research purpose is to identify eand analyze development model of work satisfaction for facing turnover intention in PT. Kitadin Site Embalut (East Borneo). The Research formulation of problem are; 1. Do the performances of flow finance treasury system in region corporation Air MinumTirtakencanaSamarinda that used measurement liquidity ratio (treasury operation flow) in year 2015 up to 2017 experience an increase? 2. Is the performance of flow finance treasury in region corporation Air minum tirta kecana Samarinda that used measurement liquidity ratio (total debt) in year 2015 up to 2017 experience an increase? 3. Is the performance of flow finance treasury in region corporation Air Minum Tirta KencanaSamarinda that used measurement liquidity ratio (Spending Fund) in year 2015 up to 2017 experience an increase? 4. Does the performance of flow finance treasury in region corporation Air Minum Tirta Kencana Samarinda that used measurement flexibility ratio (Flow Treasury Clear and open) in year 2015 up to 2017 experience an increase?

Basic Theory which author applied is Finance Accounting. Analystis insruments that author used are 1. Liquidity Ratio (Flow treasury operation). 2. Liquidity Ratio (Total debt). 3. Liquidity ratio (Spending Fund). 4. Flexibility Ratio (Clear and Open Treasury Flow. The hypothesis examined if the performance of finance treasury of region corporation air minum at samarinda experience an increase from year of 2015 up to 2017 so it comes to decision to accept the hypothesis and otherwise if the performances of finance treasury of region corporation air minum at samarinda experience a decrease from year 2015 up to 2017 the hypothesis will be decline.
\end{abstract}

Keywords : Cash Flows, Financial Performance, Turnover Intention.

\section{PENDAHULUAN}

Sumber daya manusia (SDM) merupakan satu-satunya aset penting organisasiyang dapat menggerakkan sumber daya lainnya. Sumber daya manusia dapatmempengaruhi efisiensi dan efektivitas organisasi (Simamora, 2016). Hal tersebutlah yang membuat para pebisnis pertambangan sadar akan nilai investasi karyawan sebagai sumberdaya manusia. Saat ini mengumpulkan tenaga kerja yang cakap dan berkinerjabaik semakin sulit dilakukan, terlebih lagi mempertahankan yang sudah ada. Mereka harus memprioritaskan untuk menemukan, mempekerjakan, memotivasi, melatih, mengembangkan karyawan yang paling dekat dengan budaya perusahaan dan performa yang dikehendaki, serta mempertahankan karyawan berkualitas (Pophal, 2016).

Disinilah dituntut adanya peranan penting manajemen sumber daya manusia (MSDM) dalam sebuah bisnis 
pertambangan. Manajemen sumber daya manusia adalah aktivitas yang penting disebuah organisasi. Organisasi perlu memanage sumber daya manusia untuk mencapai tujuannya secara efektif, dengan senantiasa melakukan investasi untuk penerimaan, penyeleksian dan mempertahankan sumber daya manusia yang potensial agar tidak berdampak pada perpindahan karyawan (Anis et al., 2013).

Perpindahan karyawan (employee turnover) adalah suatu fenomena yang sering terjadi dalam industri batu bara (coal industry). Turnover dapat diartikan sebagai pergerakan tenaga kerja keluar dari organisasi. Turnover mengarah pada kenyataan akhir yang dihadapi suatu organisasi berupa jumlah karyawan yang meninggalkan organisasi pada periode tertentu, sedangkan keinginan karyawan untuk berpindah (turnover intentions) mengacu pada hasil evaluasi individu mengenai kelanjutan hubungan dengan organisasi yang belum diwujudkan dalam tindakan pasti meninggalkan organisasi. Turnover dapat berupa pengunduran diri, perpindahan keluar unit organisasi, pemberhentian atau kematian anggota organisasi.

Saat ini tingginya tingkat turnover karyawan telah menjadi masalah serius bagibanyak perusahaan. Woods dan Macaulay (2009) menjelaskan bahwa turnover yang tinggi pada hospitality industry dapat mengganggu operasi, melahirkan permasalahan moral pada karyawan yang tinggal, dan juga melambungkan biaya dalam rekrutmen, wawancara, tes, pengecekan referensi, biaya administrasi pemrosesan karyawan baru, tunjangan, orientasi, dan biaya peluang yang hilang karena karyawan harus mempelajari keahlian yang baru. Rousseau (2014) menambahkan bahwa biaya atau kerugian atas adanya turnover meliputi biaya langsung yang terkait dengan kegiatan rekrutmen (antara lain biaya iklan, biaya agen) dan biaya pencarian; biaya tidak langsung misalnya biaya biaya yang berhubungan dengan pelatihan karyawan baru; dan kerugian produktivitas oleh proses pembelajaran karyawan baru.

Banyak hal yang disinyalir sebagai penyebab keluarnya seorang karyawan dari suatu pekerjaan. Situasi kerja yang dihadapi saat ini tidak sesuai dengan harapan yang diinginkan (timbulnya ketidakpuasan dalam bekerja) atau dipengaruhi oleh pandangan karyawan untuk mendapatkan alternatif pekerjaan dan kepuasan yang lebih baik. Suatu perusahaan dituntut untuk dapat mempertahankan karyawannya, seperti mampu memberikan balas jasa tinggi dan memahami hal-hal yang mampu membuat karyawannya kerasan untuk tetap bekerja 
tanpa menurunkan kinerja perusahaan tersebut secara keseluruhan.

Turnover karyawan juga terjadi pada salah satu Perusahaan tambang di PT Kitadin yang berlokasi di Embalut PT Kitadin yang didirikan pada bulan Mei 2005 merupakan salah satu ITM Group Perusahaan Tambang Site Embalut yang memiliki + 144 karyawan. Dari jumlah karyawan tersebut, $40 \%$ adalah karyawan out-sourching, karyawan casual dan karyawan magang. Sedangkan $60 \%$ adalah karyawan yang langsung direkrut dan diseleksi langsung oleh manajemen PT Kitadin Jakarta, dan kemudian disebut sebagai karyawan tetap. Seluruh karyawan tetap PT Kitadin Site Emablutakan digunakan sebagai sampel dalam penelitian ini.
Perekrutan karyawan di PT Kitadin Site Embalut tersebut adalah dengan sistem kontrak. Karyawan dikontrak untuk bekerja selama 2 (dua) tahun, dengan masa percobaan $3-6$ bulan dan setelah itu baru dilakukan evaluasi untuk memutuskan apakah karyawan yang bersangkutan akan diangkat menjadi karyawan tetap, tetap dalam posisi kontrak sebagai karyawan atau diadakan pemutusan hubungan kerja terhadap karyawan tersebut. Sistem seperti inilah yang merupakan salah satu hal yang berpengaruh terhadap tingkat turnover yang relatif tinggi pada perusahaan tersebut.

Berikut adalah nilai prosentase (\%) turnover karyawan PT Kitadin Tandung Mayang Site Embalut tahun 2013 - 2017, yang diformulasikan berdasarkan tabel berikut:

Tabel 1 Data Rata-rata Turnover Karyawan PT Kitadin Tandung Mayang Site Embalut Tahun 2013-2017

\begin{tabular}{|c|c|c|c|c|c|c|c|c|c|c|c|c|c|c|c|}
\hline \multicolumn{3}{|c|}{2013} & \multicolumn{3}{|c|}{2014} & \multicolumn{3}{|c|}{2015} & \multicolumn{3}{|c|}{2016} & \multicolumn{3}{|c|}{2017} & \multirow[t]{2}{*}{ RATA } \\
\hline $\mathrm{ML}$ & OUT & $\%$ & $J M L$ & OUT & $\%$ & $J M L$ & OUT & $\%$ & $J M L$ & OUT & $\%$ & $J M L$ & OUT & $\%$ & \\
\hline 161 & 10 & 6.21 & 211 & 52 & 24.64 & 193 & 107 & 55.44 & 153 & 67 & 43.79 & 142 & 32 & 22.54 & 30.52444 \\
\hline
\end{tabular}

Sumber : Departemen HRD PT Kitadin Site Embalut 
Tabel 2 Data Turnover Karyawan per Bulan PT Kitadin Tandung Mayang Site Embalut Tahun 2013-2017

\begin{tabular}{|c|c|c|c|c|c|c|c|c|c|c|c|c|c|c|c|}
\hline \multirow[t]{2}{*}{ BULAN } & \multicolumn{3}{|c|}{2013} & \multicolumn{3}{|c|}{2014} & \multicolumn{3}{|c|}{2015} & \multicolumn{3}{|c|}{2016} & \multicolumn{3}{|c|}{2017} \\
\hline & $J M L$ & OUTS & & $J M L$ & OUT & $\%$ & JML & OUT & & $J M L$ & OUT & & $J M L$ & OUT & $\%$ \\
\hline JAN & 0 & 0 & 0 & 204 & 3 & 1.47 & 218 & 9 & 4.13 & 167 & 12 & 7.19 & 146 & 4 & 2.74 \\
\hline FEB & 0 & 0 & 0 & 204 & 3 & 1.47 & 217 & 7 & 3.23 & 165 & 2 & 1.21 & 144 & 8 & 5.56 \\
\hline MARET & 0 & 0 & 0 & 205 & 4 & 1.95 & 216 & 9 & 4.17 & 165 & 0 & 0 & 139 & 7 & 5.04 \\
\hline APRIL & 39 & & 0 & 202 & 7 & 3.47 & 193 & 29 & 15 & 161 & 8 & 4.97 & 141 & 8 & 5.67 \\
\hline MEI & 143 & & 0 & 204 & 3 & 1.47 & 193 & 8 & 4.15 & 158 & 6 & 3.8 & 141 & 5 & 3.55 \\
\hline JUNI & 160 & 1 & 0.6 & 203 & 5 & 2.46 & 190 & 9 & 4.74 & 158 & 7 & 4.43 & & & \\
\hline JULI & 174 & & 0 & 217 & 4 & 1.84 & 185 & 10 & 5.41 & 152 & 6 & 3.95 & & & \\
\hline AGUSTUS & 175 & 3 & 1.7 & 221 & 6 & 2.71 & 189 & 4 & 2.12 & 148 & 5 & 3.38 & & & \\
\hline SEPTEMBER & 176 & 3 & 1.7 & 218 & 6 & 2.75 & 183 & 8 & 4.37 & 145 & 5 & 3.45 & & & \\
\hline OKTOBER & 186 & 1 & 0.5 & 219 & 4 & 1.83 & 180 & 6 & 3.33 & 137 & 6 & 4.38 & & & \\
\hline NOVEMBER & 199 & & 0 & 220 & 2 & 0.91 & 178 & 5 & 2.81 & 141 & 3 & 2.13 & & & \\
\hline DESEMBER & 200 & 2 & 1 & 219 & 5 & 2.28 & 179 & 3 & 1.68 & 143 & 7 & 4.9 & & & \\
\hline TOTAL & 161 & 10 & 6.2 & 211 & 52 & 24.6 & 193 & 107 & 55.4 & 153 & 67 & 43.8 & 142 & 32 & 22.5 \\
\hline
\end{tabular}

Sumber : Departemen HRD PT Kitadin Tandung Mayang Site Embalut

Berdasarkan data di atas, dapat disimpulkan bahwa sejak April 2013 sampai dengan Mei 2017, angka turnover karyawan PT Kitadin Site Embalut tergolong tinggi. Tahun 2015 mengalami peningkatan pesat dari tahun 2014 sampai dengan $30,80 \%$. Khususnya pada bulan April 2016, angka turnover karyawan sampai dengan $15,03 \%$. Dan terhitung dari April 2013 sampai dengan Mei 2017, karyawan PT. Kitadin Tandung Mayang yang keluar mencapai angka 268 orang $(31,16 \%)$ dari keseluruhan karyawan. Rumusan Masalah dalam penelitian ini dapat dirumuskan sebagai berikut:

1. Bagaimana pengaruh kepuasan kerja terhadap komitmen organisasional ?
2. Bagaimana pengaruh komitmen organisasional terhadap turnover intensions?

3. Bagaimana pengaruh kepuasan kerja terhadap turnover intensions?

\section{TINJAUAN PUSTAKA}

\subsection{Konsep-Konsep Dasar}

\section{Intensi Keluar (Turnover Intensions)}

Intensi adalah niat atau keinginan yang timbul pada individu untuk melakukansesuatu.Sementara turnover adalah berhentinya atau penarikan diri seseorang karyawandari tempat bekerja.Dengan demikian, turnover intentions (intensi keluar) adalahkecenderungan atau niat karyawan untuk berhenti bekerja dari pekerjaannya (Zeffane, 2014). 
Kepuasan Kerja

Kepuasan kerja adalah suatu efektivitas atau respon emosional terhadap berbagai aspek pekerjaan (Kreitner dan Kinicki, 2013). Definisi ini tidak dapat diartikan sebagai suatu konsep tunggal. Seseorang dapat relatif puas dengan suatu aspek dari pekerjaannya dan tidak puas dengan salah satu atau lebih aspek yang lainnya.

Kepuasan adalah cermin dari perasaan seseorang terhadap pekerjaannya. Robbin (2013) mendefinisikan kepuasan kerja adalah suatu sikap umum seorang individu terhadap pekerjaannya, selisih antara banyaknya ganjaran yang diterima seorang pekerjadan banyaknya yang mereka yakini seharusnya mereka terima. Kepuasan kerja ditentukan oleh beberapa faktor yakni kerja yang secara mental menantang, kondisi kerja yang mendukung, rekan kerja yang mendukung, serta kesesuaian kepribadian dengan pekerjaan.

\section{Komitmen Organisasional}

Komitmen organisasional secara tradisional dipandang sebagai konstruk unidimensi/satu dimensi (Porter et al., 2014). Namun demikian, terdapat bukti yang menunjukkan bahwa individu mengembangkan komitmen pada organisasi tertentu melalui berbagai dimensi atau sumber-sumber. Menurut Meyer et al., (2010) dimensi berganda komitmen organisasional mempunyai hubungan yang berbeda terhadap maksud turnover dan perilaku yang berkaitan dengan pekerjaan lainnya.

Komitmen organisasional didefinisikan sebagai keadaan dalam mana seseorang karyawan memihak pada suatu organisasi tertentu dengan tujuantujuannya, serta berniat memelihara kanggotaannya dalam organisasi tersebut (Blau dan Boal, 2009 ; dalam Ardiansah et al., 2013). Luthans (2009) dalam bukunya Perilaku Organisasi mendefinisikan komitmen organisasi sebagai sikap, yaitu :

1. Keinginan kuat untuk tetap sebagai anggota organisasi tertentu.

2. Keinginan untuk berusaha keras sesuai keinginan organisasi.

3. Keyakinan tertentu, dan penerimaan nilai dan tujuan organisasi.

2.2. Pengembangan Kerangka Berfikir Manajerial (Pengaruh Kepuasan Kerja terhadap Komitmen Organisasional)

Kepuasan kerja dan komitmen organisasional berhubungan, tetapi keduanyamerupakan sikap yang dapat dibedakan.Kepuasan kerja berhubungan dengan tanggapan efektif terhadap lingkungan kerja dengan segera, sedangkan komitmen organisasional lebih stabil dan tahan lama (Norrish dan Niebuhr, 2013). Pekerja mungkin hanya sementara tidak menyenangi pekerjaannya, tetapi tetap komitmen dengan 
organisasinya. Menurut Gregson (2012), kepuasan kerja adalah sebagai pertanda awal komitmen organisasional.

Kepuasan kerja menunjukkan kesesuaian antara seseorang yang timbul dan imbalan yang disediakan pekerjaan (Kreitner \& Kinicki, 2013). Harapanharapan yang terpenuhi tersebut dapat mengarah pada adanya suatu komitmen individu dengan organisasinya. Seseorang yang memiliki komitmen tinggi akan memiliki identifikasi terhadap organisasi, terlibat sungguh-sungguh dalam kepegawaian dan ada loyalitas serta afeksi positif terhadap organisasi. Selain itu tampil tingkah laku berusaha ke arah tujuan organisasi dan keinginan untuk tetap bergabung dengan organisasi dalam jangka waktu lama (Luthans, 2009).

\subsection{Hipotesis}

Berdasarkan uraian di atas, dapat disimpulkan sementara melalui hipotesis penelitian adalah sebagai berikut :

H1 : Kepuasan kerja berpengaruh positif terhadap komitmen organisasional.

$\mathrm{H} 2$ : Komitmen organisasional berpengaruh negatif terhadap turnover intentions.

H3: Kepuasan kerja berpengaruh negatif terhadap turnover intention

\section{METODE PENELITIAN}

\subsection{Teknik Analisis Data}

Penelitian ini digunakan analisis kuantitatif. Persepsi respondenmerupakan data kualitatif yang akan diukur dengan suatu skala sehingga hasilnya berbentuk angka. Selanjutnya angka atau skor tersebut diolah dengan metode statistik. Pengukuran metode ini adalah untuk mempermudah proses analisis data.

Dari berbagai macam alat analisis, peneliti menentukan beberapa alat analisis yang sesuai dengan kebutuhan guna pembuktian hubungan hipotesisi penelitian. Alatanalisis yang digunakan dalam penelitian ini ada dua jenis, yaitu untuk menguji data yang kedua, yaitu untuk menguji model.

1. Uji data

a. Uji normalitas univariat / multivariat

b. Uji outlinersunivariat / multivariat

2. Uji model

a. Goodness of fit

b. Uji pengaruh (regresion weight)

Selanjutnya untuk menganalisis data, peneliti menggunakan program StructuralEquation Modelling (SEM) yang dioperasikan melalui program paket software statistic AMOS. SEM merupakan kombinasi dari analisis faktor dan analisis regresi. Teknik SEM memungkinkan seorang peneliti menguji beberapa variabel dependen sekaligus, dengan beberapa variabel independen.SEM merupakan sekumpulan teknik statisticyang dapat digunakan untuk menganalisis permasalahan penelitian yang memiliki rangkaian hubungan yang relatif "rumit" 
dengan pengujian statistik secara simultan(Ferdinand, 2012).

Penggunaan program AMOS dikarenakan sesuai untuk menganalisis masalah yang sifatnya struktural, dan digunakan untuk menganalisis dan menguji model hipotesis, sebab program AMOS dapat digunakan :

1. Mengestimasi koefisien yang tidak diketahui dari persamaan linier struktural; mengakomodasi model yang meliputi variabel laten; mengakomodasi pengukuran error baik dependen maupun independen; mengakomodasi permasalahan sebab akibat, simultan dan saling ketergantungan.

2. Kelebihan SEM adalah dapat menganalisa multivariat secara bersamaan. Sedangkan tujuan pengunaan teknik multivariat adalah untuk memperluas kemampuan menjelaskan peneliti dan mencapai efisiensi statistik. Alasan menariknya teknik analisis dengan SEM adalah :

a. Menyediakan metode yang mampu menjelaskan banyak hubungan (multirelationships) secara simultan, cepat dan efisien secara statistik

b. Kemampuannya menaksir hubungan (relationship) secara komprehensiftelah membuat sebuah peralihan dari exploratory ke explanatory (Hairet.al., 2015).

Dengan pertimbangan tersebut maka AMOS digunakan untuk menguji model penelitian yang diajukan dalam kerangka pikir teoritis. Dengan SEM ini akan dilakukan pengujian statistik model penelitian secara simultan.

\subsection{Pengembangan Diagram Alur (Path}

Diagram) untuk Menunjukkan

Hubungan Kausalitas Variabel.

Path diagram akan mempermudah peneliti melihat hubungan-hubungan kausalitas variabel yang akan diuji. Peneliti biasanya bekerja dengan "construct"atau "factor" yaitu konsepkonsep yang memiliki pijakan teoritis yang cukup untuk menjelaskan berbagai bentuk hubungan.

Dalam menyusun diagram alur, hubungan antar konstruk akan dinyatakan melalui anak panah. Anak panah yang lurus menunjukkan hubungan kausal yang langsung antara satu konstruk dengan konstruk lainnya. Sedangkan garis lengkung antar kontruk dengan anak panah pada setiap ujungnya menunjukkan korelasi antar konstruk. Konstruk yang dibangun dalam diagram alur dapat dibedakan dalam 2 kelompok konstruk (Ferdinand, 2012), yaitu :

a. Konstruk eksogen (exogenous construct), dikenal juga sebagai "sourcevariables" atau "independent 
varibles", yang tidak diprediksi oleh variabel laindalam model. Konstruk eksogen adalah konstruk yang dituju oleh garis dengan satu ujung panah.

b. Konstruk endogen merupakan factor faktor yang diprediksi oleh satu atau beberapa konstruk. Konstruk endogen dapat memprediksi satu atau beberapakonstruk endogen lainnya, tetapi konstruk eksogen hanya dapat berhubungan kausal dengan konstruk endogen. Berdasarkan pijakan teoritis yang cukup, seorang peneliti akan menentukan mana yang akan diperlakukan sebagai konstruk endogen dan mana sebagai variabel eksogen.

\section{Gambar 1 Diagram Alur}

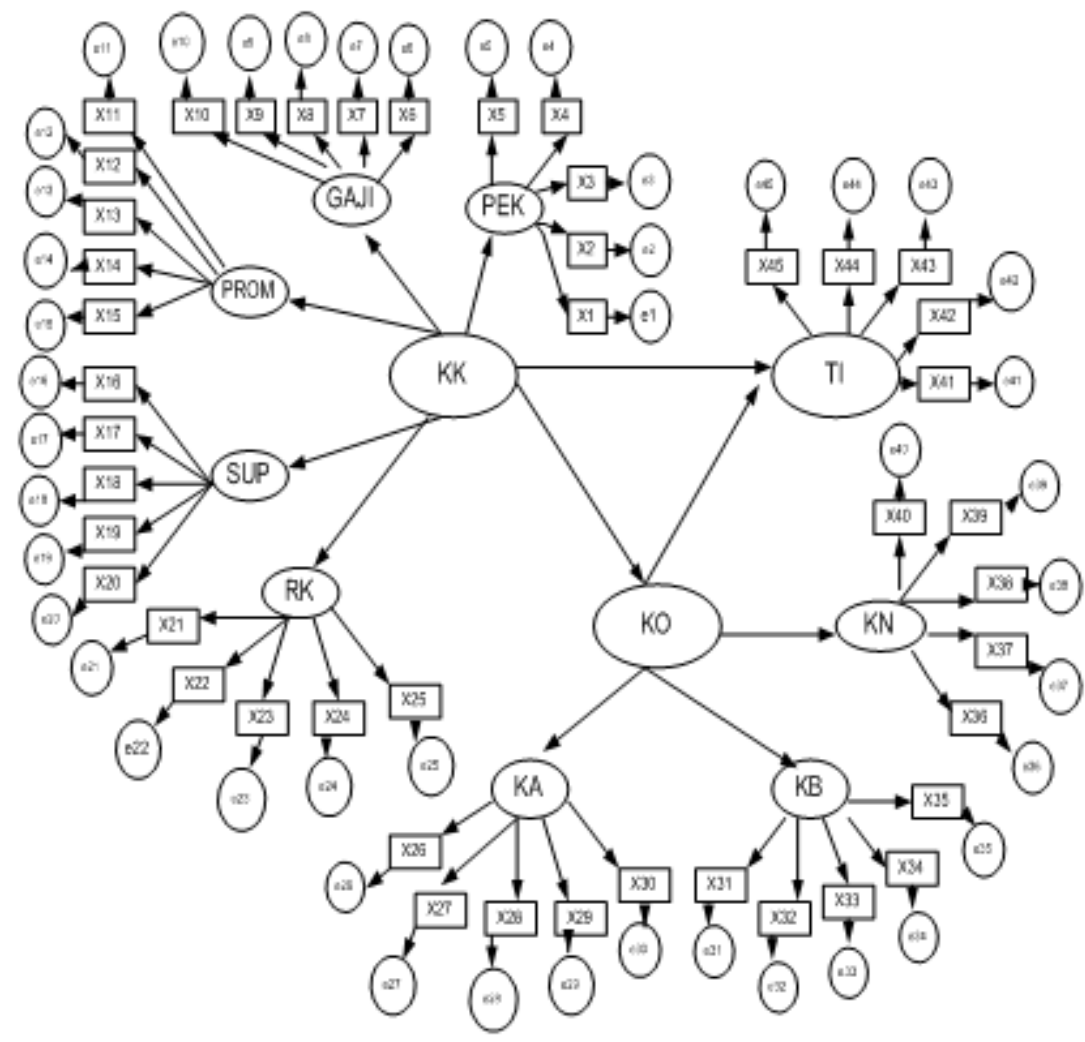

\subsection{Konversi Diagram Alur ke dalam} Serangkaian Persamaan Struktural dan Spesifikasi Model Pengukuran.

Setelah teori / model teoritis dikembangkan dan digambarkan dalam sebuah diagram alur, peneliti dapat mulai mengkonversi spesifikasi model tersebut ke dalam serangkaian persamaan.
Persamaan yang akan dibangun terdiri dari:

a. Persamaan-persamaan struktural (structural equation), yang dirumuskan untuk menyatakan hubungan kausalitas antar berbagai konstruk. Pada dasarnya dibangun dengan pedoman sebagai berikut: 
$\zeta 1, \zeta 2=$ error

Dalam Diagram Alur (Path Diagram) seperti pada gambar 3.1. jika dilakukan konversi ke dalam persamaan struktural maka akan menjadi:

$$
\begin{aligned}
& \eta 1=\lambda 1.1 \xi 1+\zeta 1 \ldots . .(1) \\
& \eta 2=\lambda 2.1 \xi 1+\beta 2.1 \eta 1+\zeta 2 \ldots .(2)
\end{aligned}
$$

Keterangan :

$\eta 1=$ Komitmen Organisasi

$\eta 2=$ Turnover Intentions

$\xi 1=$ Kepuasan Kerja

$\lambda 1.1, \quad \lambda 2.1, \quad \beta 2.1=$ Koefisien

(Hubungan antar Variabel) b. Persamaan spesifikasi model pengukuran (measurement model), yaitu menentukan variabel mana mengukur konstruk mana, serta menentukan serangkaian matriks yang menunjukkan korelasi yang dihipotesakan antar konstruk atau variabel. Persamaan untuk model pengukuran dari masing-masing konstruk pada gambar $3.2 \mathrm{di}$ atas adalah sebagai berikut :

Tabel 3 Konversi Diagram Path dalam Model Matematik

\section{Konstruk Eksogen}

(Model Pengukuran)

\section{Konstruk Endogen}

(Model Pengukuran)
$\mathrm{X26}=\lambda 26 \eta 1+\varepsilon 26$

$X 27=\lambda 27 \eta 1+\varepsilon 27$

$\mathrm{X} 28=\lambda 28 \eta 1+\varepsilon 28$

$X 29=\lambda 29 \eta 1+\varepsilon 29$

$X 30=\lambda 30 \eta 1+\varepsilon 30$

$X 31=\lambda 31 \eta 1+\varepsilon 31$

$X 32=\lambda 32 \eta 1+\varepsilon 32$

$X 33=\lambda 33 \eta 1+\varepsilon 33$

$X 34=\lambda 34 \eta 1+\varepsilon 34$

$\mathrm{X35}=\lambda 35 \eta 1+\varepsilon 35$

$X 36=\lambda 36 \eta 1+\varepsilon 36$

$\mathbf{X 3 7}=\lambda \mathbf{3 7} \boldsymbol{\eta} \mathbf{1}+\varepsilon 37$

$\mathrm{X38}=\lambda 38 \eta 1+\varepsilon 38$

$X 39=\lambda 39 \eta 1+\varepsilon 39$

$X 40=\lambda 40 \eta 1+\varepsilon 40$

$\mathrm{X} 41=\lambda 41 \eta 2+\varepsilon 41$ 


$$
\begin{aligned}
& \mathrm{X} 17=\lambda 17 \xi 1+\varepsilon 717 \\
& \mathrm{X} 18=\lambda 18 \xi 1+\varepsilon 18 \\
& \mathrm{X} 19=\lambda 19 \xi 1+\varepsilon 19 \\
& \mathrm{X} 20=\lambda 20 \xi 1+\varepsilon 20 \\
& \mathrm{X} 21=\lambda 21 \xi 1+\varepsilon 21 \\
& \mathrm{X} 22=\lambda 22 \xi 1+\varepsilon 22 \\
& \mathrm{X} 23=\lambda 23 \xi 1+\varepsilon 23 \\
& \mathrm{X} 24=\lambda 24 \xi 1+\varepsilon 24 \\
& \mathrm{X} 25=\lambda 25 \xi 1+\varepsilon 25
\end{aligned}
$$

Sumber : dikembangkan untuk penelitian ini

Umumnya terdapat beberapa jenis fit index yang digunakan untuk mengukur derajat kesesuaian antara model yang dihipotesiskan dan data yang disajikan. Beberapa indeks kesesuaian dan cut-off value yang dapat digunakan untuk menguji apakah suatu model dapat diterima atau ditolak (Ferdinand, 2012) adalah sebagai berikut :

\section{1) $\chi^{2}-$ Chi Square}

Merupakan alat uji paling fundamental untuk mengukur overall fit. Chisquare bersifat sangat sensitive terhadap besarnya sampel yang digunakan, dimana penggunaan chi-square hanya sesuai bila ukuran sample antara 100 sampai 200 sampel. Model yang diuji dipandang baik atau memuaskan bila nilaichi square-nya rendah karena dalam uji bedachi square, $\chi^{2}=0$ berarti benar benar tidak ada perbedaan. Semakin kecil nilai $\chi^{2}$ semakin baik model itu dan diterima berdasarkan probabilitas dengan

$$
\begin{aligned}
& \mathrm{X} 42=\lambda 42 \eta 2+\varepsilon 42 \\
& \mathrm{X} 43=\lambda 43 \eta 2+\varepsilon 43 \\
& \mathrm{X} 44=\lambda 44 \eta 2+\varepsilon 44 \\
& \mathrm{X} 45=\lambda 45 \eta 2+\varepsilon 45
\end{aligned}
$$

cut-off value sebesar $\mathrm{p}>0,05$ atau $\mathrm{p}>0,10$ (Hulland et al., 2016).

\section{2) Probability}

Nilai probability yang dapat diterima adalah $\mathrm{P}>0,05$.

3) RMSEA (The Root Mean Square Error of Approximation)

Merupakan sebuah indeks yang dapat digunakan untuk mengkompensasi chisquarestatistic dalam sampel yang besar (Baumgarther \& Homburg, 201). Nilai RMSEA menunjukkan nilai goodness-of-fit yang dapat diharapkan bila model diestimasi dalam populasi (Hair, et.al, 2015). Nilai RMSEA yang lebih kecil atau sama dengan 0.08 merupakan indeks untuk dapat diterimanya model yang menunjukkan sebuah close fit dari model tersebut berdasarkan degrees offreedom (Browne dan Cudeck, 2013)

\section{4) GFI (Goodness of Fit Index)}

Indeks kesesuaian ini akan menghitung proporsi tertimbang dari 
varians dalam kovarians sampel yang dijelaskan oleh matriks kovarians populasi yang diestimasikan. GFI adalah sebuah ukuran non-statistikal yang mempunyai rentang antara 0 (poor fit) s.d 1.0 (perfect fit). Nilai yang tinggi dalam indeks ini menunjukkan sebuah "better fit".

5) AGFI (Adjusted Goodness of Fit Index)

Fit index ini dapat diadjust terhadap degrees of freedom yang tersedia untuk menguji diterima tidaknya model. Tingkat penerimaan yang direkomendasikan adalah bila AGFI mempunyai nilai sama dengan atau lebih besar dari 0,90 (Hairet al., 2016; Hulland et al., 2016) nilai sebesar 0,95 dapat diinterpretasikan sebagai tingkatan yang baik/ good overall model fit (baik), sedangkan besaran nilai antara 0,90-0,95 menunjukkan tingkatan cukup adequate fit (Hulland etal., 2016)

6) $\mathrm{CMIN} / \mathrm{DF}$

Hal ini CMIN/DF tidak lain adalah statistik chi-square, $\chi^{2}$ dibagi degreeof freedom (DF), sehingga disebut $\chi^{2}$ - relatif. Nilai $\chi 2$ relatif kurang dari 2,0 atau bahkan kadang kurang dari 3,0 adalah indikasi dari acceptable fit antara modeldan data (Arbuckle, 2017).

7) TLI - Tucker Lewis Index

TLI adalah sebuah alternative incremental fit index yang membandingkan sebuah model yang diuji terhadap sebuah baseline model. Nilai yang direkomendasikan sebagai acuan untuk diterimanya sebuah model adalah > 0,95(Hair et al., 2015), dan nilai yang sangat mendekati 1 menunjukkan a very goodfit (Arbuckle, 2017).

8) CFI - Comparative Fit Index

Nilai index ini antara 0-1, dimana semakin mendekati 1 mengindikasikan tingkat fit yang paling tinggi. Nilai yang direkomendasikan adalah CFI $>0,95$. Keunggulan indeks ini adalah besarannya tidak dipengaruhi ukuran sampel karena sangat baik untuk mengukur tingkat penerimaan sebuah model (Hullandet al., 2016; Tanaka, 2013). Indeks-indeks untuk menguji kelayakan sebuah model adalah sebagai berikut (Ferdinand, 2012):

Tabel 4 Indeks Pengujian Kelayakan Model (Goodness-of-fit Index)

Goodness of fit index
Cut of Value

Significancy probability $\quad \geq 0.05$

RMSEA $\leq \mathbf{0 . 0 8}$ 


\begin{tabular}{ll} 
GFI & $\geq 0.90$ \\
\hline AGFI & $\geq 0.90$ \\
\hline CMIN/DF & $\leq 2.00$ \\
\hline TLI & $\geq 0.95$ \\
\hline CFI & $\geq 0.95$
\end{tabular}

Sumber : Ferdinand, 2012

\subsection{Interpretasi dan Modifikasi Model}

Langkah terakhir adalah

menginterpretasikan model atau memodifikasi model bagimodel-model yang tidak memenuhi syarat pengajuan yang dilakukan. Setelah model diestimasi, residualnya haruslah kecil atau mendekati nol dan distribusi frekuensi dari kovarians residual harus bersifat simetrik. Hair et al., (2015) dalam Ferdinand (2012) memberikan pedoman untuk mempertimbangkan perlu tidaknya memodifikasi sebuah model dengan melihat jumlah residual yang dihasilkan oleh model. Bila ditemukan nilai residual yang dihasilkan model cukup besar (yaitu > 2,58), maka cara lain dalam memodifikasi adalah dengan mempertimbangkan untuk sebuah alur baru terhadap model yang diestimasi itu. Nilai residual $\geq 2,58$ diinterpretasikan sebagai signifikan secara statistik pada tingkat 5 persen $(\%)$.

\section{HASIL DAN PEMBAHASAN}

Semakin tinggi kepuasan kerja, maka semakin tinggi komitmen organisasional. Seseorang yang telah terpenuhi semua kebutuhan dan keinginan oleh organisasi (puas), secara otomatis dengan penuh kesadaran mereka akan meningkatkan tingkat komitmen yang ada adalam dirinya. Dengan demikian, variabel yang positif terhadap kepuasan kerja yaitu tipe pekerjaan itu sendiri, gaji dan bayaran, kesempatan promosi, atasan dan rekan kerja dapat terpenuhi, maka komitmen terhadap organisasi akan timbul dengan baik (Luthan, 2015). Hal ini mendukung hasil penelitian sebelumnya yang dilakukan Bartol (2009); Riecher (2015); DeMicco dan Reid (2008); Johnson et al., (2010); Lam dan Zhang (2013) dan Chen (2017).

Semakin tinggi komitmen organisasional, maka semakin rendah pula tingkat turnover intentions.

Hal ini berbanding dengan hipotesis sementara peneliti dan sesuai dengan kesimpulan para peneliti sebelumnya yang 
menyatakan bahwa semakin tinggi komitmen organisasional, maka semakin rendah turnover intentions. Namun hasil penelitian ini tidak sesuai dengan penelitian lain sebelumnya seperti yang dilakukan Mathieu dan Zaiac (2010); Tett dan Meyer (2013) yang menyatakan bahwa komitmen organisasional tidak memiliki pengaruh kuat terhadap turnover intentions.

\section{Semakin tinggi kepuasan kerja, maka semakin rendah tingkat turnover intentions.}

Individu yang merasa terpuaskan dengan pekerjaannya cenderung untuk bertahan dalam organisasi. Sedangkan individu yang merasa kurang terpuaskan dengan pekerjaannya akan memilih keluar dari organisasi. Robbins (2013) menjelaskan bahwa kepuasan kerja dihubungkan negatif dengan keluarnya karyawan, tetapi faktorfaktor lain seperti pasar kerja, kesempatan kerja alternatif dan panjangnya masa kerja merupakan kendala penting untuk meninggalkan pekerjaan yang ada. Hasil penemuan yang ada telah mendukung penelitian sebelumnya yang dilakukan Kalbers \& Fogarty (2015); Passewark \& Strawser (2016); Lum et al., (2008) dan Tett \& meyer (2013).

\section{KESIMPULAN DAN SARAN}

Kesimpulan
Berdasarkan bukti-bukti empiris yang diperoleh dari penelitian-penelitian terdahulu, maka peneliti mengembangkan tiga buah hipotesis yang melibatkan tiga buah variable penelitian, yaitu kepuasan kerja, komitmen organisasional dan turnover intentions. Melalui penyebaran terhadap 144 responden karyawan PT. Kitadin Site Embalut, dan selanjutnya dianalisis dengan teknik analisis Structural Equation Modeling (SEM), maka penelitian ini menghasilkan 3 (tiga) kesimpulan empiris.

Pertama, semakin tinggi kepuasan kerja, maka semakin tinggi komitmen organisasional. Seseorang yang telah terpenuhi semua kebutuhan dan keinginan oleh organisasi (puas), secara otomatis dengan penuh kesadaran mereka akan meningkatkan tingkat komitmen yang ada adalam dirinya. Dengan demikian, variabel yang positif terhadap kepuasan kerja yaitu tipe pekerjaan itu sendiri, gaji dan bayaran, kesempatan promosi, atasan dan rekan kerja dapat terpenuhi, maka komitmen terhadap organisasi akan timbul dengan baik (Luthan, 2015). Hal ini mendukung hasil penelitian sebelumnya yang dilakukan Bartol (2009); Riecher (2015); DeMicco dan Reid (2008); Johnson et al., (2010); Lam dan Zhang (2013) dan Chen (2017).

Kedua, semakin tinggi komitmen organisasional, maka semakin rendah pula 
tingkat turnover intentions. Hal ini berbanding dengan hipotesis sementara peneliti dan sesuai dengan kesimpulan para peneliti sebelumnya yang menyatakan bahwa semakin tinggi komitmen organisasional, maka semakin rendah turnover intentions. Namun hasil penelitian ini tidak sesuai dengan penelitian lain sebelumnya seperti yang dilakukan Mathieu dan Zaiac (2010); Tett dan Meyer (2013) yang menyatakan bahwa komitmen organisasional tidak memiliki pengaruh kuat terhadap turnover intentions.

Ketiga, semakin tinggi kepuasan kerja, maka semakin rendah tingkat turnover intentions. Individu yang merasa terpuaskan dengan pekerjaannya cenderung untuk bertahan dalam organisasi. Sedangkan individu yang merasa kurang terpuaskan dengan pekerjaannya akan memilih keluar dari organisasi. Robbins (2013) menjelaskan bahwa kepuasan kerja dihubungkan negatif dengan keluarnya karyawan, tetapi faktorfaktor lain seperti pasar kerja, kesempatan kerja alternatif dan panjangnya masa kerja merupakan kendala penting untuk meninggalkan pekerjaan yang ada. Hasil penemuan yang ada telah mendukung penelitian sebelumnya yang dilakukan Kalbers \& Fogarty (2015); Passewark \& Strawser (2016); Lum et al., (2008) dan Tett \& meyer (2013).
Selain itu, dapat disimpulkan juga bahwa kepuasan kerja juga berpengaruh lebih kuat secara tidak langsung terhadap turnover intentions. Hal ini sesuai dengan kesimpulan DeMicco dan Reid (2008) yang menyatakan bahwa kepuasan kerja bukanlah merupakan penyebab langsung terjadinya kemangkiran karyawan, kinerja yang rendah maupun turnover karyawan.

\section{Implikasi Teoritis}

Model penelitian dan hipotesis yang dikembangkan, didasarkan pada berbagai teori dan hasil-hasil penelitian terhadahulu. Oleh karena itu, hasil penelitian ini akan membawa beberapa implikasi terhadap teori-teori maupun hasil-hasil penelitian terdahulu yang mendasarinya, yaitu :

1. Hasil penelitian ini menunjukkan bahwa kepuasan kerja terbukti memiliki pengaruh yang positif dan signifikan terhadap komitmen organisasional. Hasil penelitian ini mendukung penelitian yang dilakukan oleh Mathiew (2008), William dan Hazzer (2016), Demicco dan Reid (2008), Chen (2017), Lam and Zhang (2013), dan Bartol (2009); Riecher (2015); Johnson et al., (2010) yang juga menunjukkan hasil yang sama dengan hasil penelitian ini, yaitu semakin tinggi kepuasan kerja, maka semakin tinggi pula komitmen organisasionalnya. Hasil penelitian ini juga memperkuat teori yang disampaikan oleh Luthans (2015) dan Ganzach (2008). 
2. Hasil penelitian ini menunjukkan bahwa komitmen organisasional memiliki pengaruh yang positif dan signifikan terhadap turnover intentions. Hasil penelitian ini sejalan dengan hasil penelitian yang pernah dilakukan oleh Mathieu dan Zaiac (2010) dan mendukung penelitian yang dilakukan Tett dan Meyer (2013).

3. Hasil penelitian ini menunjukkan bahwa kepuasan kerja memiliki pengaruh yang negatif tidak signifikan terhadap turnover intentions. Dengan demikian, Penelitian ini memperkuat hasil penelitian yang pernah dilakukan oleh Demicco dan Reid (2008).

\section{Implikasi dan Saran Manajerial}

Berdasarkan hasil-hasil pengujian terhadap variabel kepuasan kerja, komitmen organisasional, dan turnover intentions, maka dapat diketahui variabel-variabel apa saja yang berpengaruh signifikan terhadap turnover intentions. Oleh karena itu, implikasi manajerial ditekankan pada variabel yang memiliki pengaruh paling besar terhadap turnover intentions.

Pertama, turnover intention terjadi dipengaruhi oleh komitmen organisasional sebesar 0.99. Tingkat turnover intention dapat diturunkan dengan melakukan upaya meningkatkan dan mempertahankan komitmen karyawan PT.Kitadin Site Embalut Samarinda yang memang sudah ada, antara lain :
1. Mengadakan sosialisasi lebih mendalam tentang profil hotel dan peraturannya, baik peraturan langsung dari pemerintah maupun peraturan dalam perusahaan. Misalnya hak dan kewajiban sebagai karyawan, kepastian sebagai pegawai tetap beserta dana pensiunnya, dan lain-lain.

2. Melibatkan karyawan dalam setiap kegiatan organisasi, baik kegiatan di dalam maupun di luar organisasi, misalnya ulang tahun PT. Kitadin Site Embalut Samarinda, kegiatan keagamaan, dan lain sebagainya.

3. Membuka wadah khusus bagi karyawan untuk berinteraksi antar sesama karyawan sehingga mampu menjembatani level top manajemen dengan karyawan biasa agar terbina suatu hubungan yang kuat antara pimpinan dengan karyawan.

4. Membuka koperasi karyawan yang berguna untuk meningkatkan kesejahteraan karyawan melalui sembako murah untuk karyawan, pemberian pinjaman kepada karyawan dengan bunga ringan, dan lain-lain yang pada akhirnya dapat menumbuhkan rasa komitmen pada organisasi.

5. Memberikan reward kepada karyawan berprestasi dan keluarganya, seperti kenaikan jabatan dan gaji, gelar-gelar khusus sesuai bidang pekerjaan yang dilakukan di PT. Kitadin Site Embalut Samarinda, beasiswa kepada karyawan 
maupun anak-anak karyawan yang berprestasi, dan lain-lain.

6. Memberikan punishment jika karyawan mengundurkan diri sebelum periode waktu yang telah disepakati sehingga mau tidak mau karyawan tersebut akan memiliki komitmen untuk tetap bekerja di PT. Kitadin Site Embalut Samarinda sampai batas waktu yang telah disepakati.

Kedua, turnover intentions terjadi dipengaruhi oleh kepuasan kerja sebesar 0.20 .

Tingkat turnover intentions dapat diturunkan dengan meningkatkan kepuasan kerja

melalui :

1. Pemberian kesempatan kepada karyawan untuk meningkatkan keterampilan misalnya kursus memasak untuk chef, dan lain-lain.

2. Pemberian insentif jika tingkat hunian hotel memenuhi target tertentu.

3. Pemberian dukungan yang dilakukan oleh penyelia dalam bentuk bimbingan / bantuan teknik di lapangan maupun dukungan perilaku.

4. Peningkatan solidaritas dan kerja sama dengan rekan kerja dalam hal pekerjaan.

\section{REFERENCES}

Andini, Rita, 2016. “Analisis Pengaruh Kepuasan Gaji, Kepuasan Kerja, Komitmen Organisasional terhadap
Turnover Intention: Studi Kasus Pada Rumah Sakit Roemani Muhammadiyah Semarang", Tesis Magister Management,Universitas Diponegoro Semarang.

Anis K, Indah, M. Noor Ardiansah \& Sutapa, 2013. "Pengaruh Kepuasan Kerja dan Komitmen Organisasional Terhadap Keinginan Berpindah Kerja Auditor (Studi Kasus pada KAP di Jawa Tengah)", Jurnal Ekonomi dan Bisnis, 4 (2): 141-152.

Ardiyanto, Didik, 2013. "Pengaruh Komitmen Organisasional Terhadap Kepuasan Kerjadan Keinginan Karyawan untuk Berpindah: Studi Empiris pada Kantor AkuntanPublik di Jawa", Jurnal Maksi, 2: 64-82.

Begley, Thomas M, and Czajka, Joseph M., 2013. "Panel Analysis of The Moderating Effects of Commitment on Job Satisfaction, Intent to Quit, and Health Following Organizational Change", Journal of Applied Psychology, 78 (4): 552 - 556.

Bohdanowicz, Paulina, 2015. "European Hoteliers' Environmental

Attitudes", Cornell Hotel and Restaurant Administration

Quarterly, May pp. 188-204. 
Chen, Tser Yieth., Pao Long Chang, and Ching Wen Yeh, 2004. "A Study of Career Needs, Career Development Programs, Job Satisfaction and The Turnover Intentions of $R \& D$ Personnel", Career Development International, .9 (1): 424-437.

Chen, Yi Jen, 2017. "Relationship Among Service Orientation, Job Satisfaction and Organizational Commitment in The International Tourist Hotel Industry", The Journal of American Academy of Business, 11 (2): 71-82. DeMicco, Frederick J and Reid, Robert D., 2008. “Older Workers: A Hiring Resource forThe Hospitality Industry", Cornell Hotel and Restaurant Administration

Quarterly, May pp. 56-62.

Ferdinand, Agusty, 2010. Structural Equation Modeling Dalam

Penelitian Manajemen, Semarang:

Badan Penerbit Universitas Diponegoro.

Ferdinand, Agusty, 2016. Metode Penelitian Manajemen, Edisi Kedua, Semarang: Badan Penerbit Universitas Diponegoro.

Ghiselli, Richard F, La Lopa, and Joseph M, Bai, Billy, 2010. “Job Satisfacton, Life Satisfaction and Turnover Intent: Among FoodService Manager", Cornell Hotela nd Restaurant Administration Quarterly, April pp. 28-37.

Grant, K., D.W. Cravens, G.S. Low and W.C. Moncrief, 2010. "The Role of Satisfaction with Territory Design on The Motivation, Attitudes, and Work Outcomes os Sales People”, Journal of The Academy of Marketing Science, 29 (2): 165-178. Hackett, R.D., Bycio, and P.A. Hausdorf, 2014. "Further Asesstments of Meyer and Allens (1991). Three component model Organizational Commitment", Journal of Applied Psychology, 79 (4): 15-23.

Hair, J.R., et al., 2008. Multivariate Data Analysis, 5th Edition, Prentice Hall International Inc.

Hom, Katerberg and Hulin, 2009. "Comparative Examination of Three Approaches to The Prediction of Turnover", Jurnal of Applied Psychology pp. 280-290.

Indriantoro, Nur., dan Bambang Supomo, 2012. Metodologi Penelitian Bisnis, Yogyakarta: Badan Penerbit Universitas Gajahmada Irwansyah, 2015. "Pengaruh Komitmen Organisasional, Kepuasan Kerja dan Keperilakuan Etis terhadap Keinginan Berpindah Profesioonal Sistem Informasi", Jurnal Bisnis Strategi, 14 (2): 181-196. 
Jenkins, Michael, Thomlinson, and R. Paul, 2012. "Organizational Commitment and JobSatisfaction as Predictors or Employee Turnover Intentions", Management Reserach News, 15: 18-22.

Kalbers, L.P., and TJ. Forgarty, 2015. "Professionalism and Its Consequences: A Study ofInternal Auditors", Auditing: A journal of Practice and Theory, 14: 64 - 86.

Kreitner, Robert and Angelo Kinicki, 2013. Perilaku Organisasi, Edisi kelima, Jakarta: Salemba Empat.

Luthans, Fred, 2016. Perilaku Organisasi, Edisi kesepuluh, Yogyakarta: Andi Offset.

Mas'ud, Fuad, 2014. Survai Diagnosis Organisasional: Konsep dan Aplikasi, Semarang: Badan Penerbit Universitas Diponegoro.

Mas'ud, Fuad,, 2016, 40 Mitos Manajemen

Sumber Daya Manusia, Semarang: Badan Penerbit Universitas Diponegoro.

McClearly, Ken $\mathrm{W}$ and Weaver, and Pamela A, 2008. "The Job Offer: What Today's Graduates Want", Cornell Hotel and Restaurant Administration Quarterly, February pp. 28-31.

Meyer, John, P., Allen, Natalie, J. and Smith, Catherina A, 2013. "Commitment to Organizational and
Occupation : Extention and Test of a Three Component Conceptualization", Journal Applied Psychology, 78 (4): 538-551.

Mobley W.H., Griffeth R.W., Hand H. H and Meglino B. M., 2009. "Review and Conceptual Analysis of Employee Turnover Process", Psychological Bulletin.

Mueller, John Dwight Kammeyer, 2013. "Turnover Process in a Temporal Context :It's about Time", retrieved from www.emeraldinsight.com, 2 August 2018.

Nahusona, Hilda CF, Rahardjo, Mudji, and Rahardjo, Susilo Toto, 2014. "Analisis Faktor-Faktor yang Berpengaruh Terhadap Keinginan Karyawan untuk Pindah: Studi Kasus pada PT. Bank Papua”, Jurnal Studi Manajemen dan Organisasi, 1 (2): 63 - 82.

Orly, Christophe, 2008. "Quality Circles in France: Accor's Experiment in Self Management", Cornell Hotel and Restaurant Administration

Quarterly, November pp. 50-56.

Pavesic, David V and Brymer, Robert A, 2010. “Job Satisfaction: What's Happening to the Young Managers", Cornell Hotel and Restaurant

AdministrationQuarterly, February pp. 90-96. 
Pasewark, W.R., and J.R. Strawser, 2016.

"The Determinants and Outcomes Associated with Job Insecurity an A Professional Accounting

Environment", Behavioral Research in Accounting, .8: 91 - 113.
Pophal, Lin Grensing, 2010. Human Resources Book: Manajemen Sumber Daya Manusia untuk Bisnis, Edisi Pertama, Jakarta: Prenada Media.

Penelitian ini didanai oleh Direktorat Jenderal Penguatan Riset dan Pengembangan Kementerian Riset, Teknologi dan Pendidikan Tinggi dengan nomor kontrak 509/KONTRAK-PENELITIAN/K11/KM/2018 Tgl 22 Februari 2018 